\title{
MNEs and human rights: From responsibilities to rights to governance
}

DOI:

10.1108/cpoib-07-2018-0063

\section{Document Version}

Accepted author manuscript

Link to publication record in Manchester Research Explorer

\section{Citation for published version (APA):}

Zagelmeyer, S. (2019). MNEs and human rights: From responsibilities to rights to governance. Critical

Perspectives on International Business. https://doi.org/10.1108/cpoib-07-2018-0063

\section{Published in:}

Critical Perspectives on International Business

\section{Citing this paper}

Please note that where the full-text provided on Manchester Research Explorer is the Author Accepted Manuscript or Proof version this may differ from the final Published version. If citing, it is advised that you check and use the publisher's definitive version.

\section{General rights}

Copyright and moral rights for the publications made accessible in the Research Explorer are retained by the authors and/or other copyright owners and it is a condition of accessing publications that users recognise and abide by the legal requirements associated with these rights.

\section{Takedown policy}

If you believe that this document breaches copyright please refer to the University of Manchester's Takedown Procedures [http://man.ac.uk/04Y6Bo] or contact uml.scholarlycommunications@manchester.ac.uk providing relevant details, so we can investigate your claim.

\section{OPEN ACCESS}




\section{Emerald $\begin{aligned} & \text { critical perspectives on } \\ & \text { international business }\end{aligned}$}

\section{MNEs and human rights: From responsibilities to rights to governance}

\begin{tabular}{|r|l|}
\hline Journal: & critical perspectives on international business \\
\hline Manuscript ID & cpoib-07-2018-0063.R3 \\
\hline Manuscript Type: & Academic Paper \\
\hline Keywords: & $\begin{array}{l}\text { Multinational Enterprises, International business, Corporate Social } \\
\text { Responsibility, Human Rights, Guiding Principles on Business and Human } \\
\text { Rights, Governance }\end{array}$ \\
\hline
\end{tabular}

\section{SCHOLARONE Manuscripts}




\title{
MNEs and human rights: From responsibilities to rights to governance ${ }^{1}$
}

\begin{abstract}
Purpose - This paper explores the links between MNEs and human rights abuses, and reviews the development of international business and human rights initiatives. Arguing that the focus of the business and human rights debate has shifted from responsibility to rights, and subsequently to governance, it proposes a framework for analysing international business and human rights governance issues in the context of social value creation.

Design/methodology/approach - The paper develops a framework for analysing business and human rights governance with respect to (i) the business and human rights field; and (ii) four business and human rights subfields (labour, consumption, community, and environment).

Findings - The analytical framework is organised around the relationships between human rights duty-bearers (companies) and human rights-holders (e.g., employees, consumers). It emphasises the role of actors and their interests, the relationships between actors, the objectives of these relationships, and the role of governance mechanisms and structures, which, for a particular human rights subfield, define the international business and human rights governance system.

Originality/value - The analytical framework can be used by international business researchers, practitioners and public policy-makers to describe, analyse, discuss and address business and human rights issues and challenges. It can be used for comparing and evaluating characteristics and properties of alternative institutional arrangements in the field of business and human rights. Furthermore, it can be used to support the design corporate non-market strategies as well as public policies.

Keywords - Multinational enterprises, International business, Corporate social responsibility, Human rights, Guiding Principles on Business and Human Rights, Governance

Paper type - Conceptual paper

\footnotetext{
${ }^{1}$ Acknowledgements: I gratefully acknowledge insightful comments received from John Budd from Carlson School of Management at the University of Minnesota, as well as from Brian Vera and Mohamed Genawi from Alliance Manchester Business School at the University of Manchester, on earlier versions of the paper.
} 
MNES AND HUMAN RIGHTS: FROM RESPONSIBILITIES TO RIGHTS TO GOVERNANCE

\section{Introduction}

The international business (IB) community has a long tradition of reflecting on the state of the field. Vibrant and constructive discussions occur at periodic intervals, providing for reflection and reorientation, and inspiring IB research to push beyond existing frontiers (Buckley, Doh, and Benischke, 2017). One recurring theme relates to the role of IB in society, with a quickly growing body of literature on corporate social responsibility (CSR). Yet, despite several initiatives at the United Nations (UN) level to establish human rights-related international standards for multinational enterprises (MNEs), such as the 2003 draft 'Norms of the Responsibilities of Transnational Corporations' and the 2011 'Guiding Principles for Business and Human Rights' (UNGPs), IB research has only recently started to engage directly with the topics of business and human rights (Giuliani, 2018; Giuliani and Macchi, 2014; Sinkovics, Hoque, and Sinkovics, 2016; Wettstein, Giuliani, Santangelo, and Stahl, 2019) and global governance (Banerjee, 2014).

This paper is a response to repeated calls to investigate the links between IB and human rights further (Giuliani, Santangelo, and Wettstein, 2016; Wettstein et al., 2019) and the issue of MNE accountability (de Jonge, 2011). It contributes in three ways to the ongoing debates. First, building on previous observations of a shift in the CSR debate from a focus on (corporate) responsibility to (human) rights (Wettstein, 2012), this paper argues that the field is now moving towards a focus on human rights governance and management. Second, it proposes a framework for analysing international business and human rights governance arrangements that can be used by IB practitioners to develop corporate nonmarket strategies, by public policy-makers to design and evaluate policies in the business and human rights field, and by researchers for evaluating and analysing the characteristics and properties of alternative institutional arrangements. Finally, it links human rights to continuing debates on CSR and sustainability (Pisani, Kourula, Kolk, and Meijer, 2017; van Zanten and van Tulder, 2018) as well as those on the role of MNEs in global governance (Ruggie, 2014).

The paper is organised as follows. The first part reviews the main business and human rights initiatives at the international level, elaborates on corporate responsibility and human rights harm, and then discusses the topic of corporate involvement in human rights abuses. The second part of the paper proposes a framework with which to analyse (international) business and human rights governance. The paper will finally discuss the relevance and implications of the framework for future IB research, management practice and public policy-makers. 


\section{International business and human rights - From responsibilities to rights to ...}

The debate on (international) business and human rights has been closely connected to the institutionalisation of international human rights driven by the UN. The purpose of this section is to set the scene for the subsequent analysis and discussion. It will first provide an overview of the main business and human rights initiatives seeking to influence the human rights-related behaviour of (international) business organizations. It will them elaborate on and discuss conceptual approaches to identify and categorise corporate involvement in human rights abuses.

\subsection{Relevant international human rights initiatives since World War II}

The International Bill of Human Rights, with its core values, principles and ideas, represents the foundation upon which the current IB and human rights regime is based. The International Bill of Human Rights includes three pillars (OHCHR, 2012). The central pillar is the Universal Declaration of Human Rights (UDHR), adopted by the UN General Assembly in 1948, which consists of thirty articles outlining the human rights of individuals. The declaration is not legally binding, but provides a reference point for international, regional and national human rights treaties, legislation and other instruments.

While the International Bill of Human Rights focuses on the responsibility and duty of the state to prevent and remedy human rights abuses, the role of business, particularly MNEs, in human rights abuses, has been scrutinised since at least the 1970s, leading to several international soft law initiatives. In 1973, the UN created the United Nations Commission on Transnational Corporations, with the objective of developing a corporate code of conduct for transnational corporations (TNCs). In 1994, the group was dissolved without agreeing on a code of conduct due to disagreement between developing and developed countries (Sauvant, 2015).

In 1998, the UN Working Group on Transnational Corporations was established with a mandate to create universal standards for the human rights obligations of transnational corporations to strengthen corporate accountability (Weissbrodt, 2005; Weissbrodt, 2008). The 2003 draft document of the 'Norms of the Responsibilities of Transnational Corporations and Other Business Enterprises with Regard to Human Rights' stipulates states as primary dutyholders to protect human rights, with transnational companies being assigned responsibilities under international human rights law with respect to a broad range of universal human rights. Governments were required to protect people from human rights harm caused by business activities. In addition, the provisions included monitoring corporate behaviour with respect to human rights and transnational enforcement mechanisms. The draft norms were received with reservation by many governments and objected to by MNEs and business associations (Deva, 
2015). Ultimately, in 2005 the UN Commission on Human Rights neglected the draft norms and instead requested the appointment of a UN Special Representative on Business and Human Rights, and the discussion of the Norms was closed down (Campagna, 2004; Feeney, 2009).

In parallel to the work of the Working Group on Transnational Corporations, the UN Global Compact (UNGC) was announced in 1999 and launched in 2000. The UNGC is a voluntary and non-binding CSR initiative to encourage companies to adopt and pursue socially responsible and sustainable policies, as established by ten business principles covering the areas of human rights, labour, environment and anti-corruption work. It seeks to bring together enterprises, civil society, labour groups and $\mathrm{UN}$ agencies to mainstream the ten business principles globally and to encourage and focus the support of its members for the UN Millennium Development Goals and the UN Sustainable Development Goals (Rasche, Waddock, and McIntosh, 2013).

The UNGC was reported to have 9,500 members in over 160 countries in 2019 (United Nations Global Compact, 2019). The initiative led to the establishment of local networks of companies, NGOs and other key actors in a forum of information exchange and discussion. Furthermore, it requires member companies to make explicit and clear statements of support and to document their progress in achieving the UNGC's ten business principles (Williams, 2004). Not intended as a normative or regulatory framework, the UNGC was intended to contribute to a 'consensus in the global community on shared values and moral norms that will guide the global economy' (Williams, 2014). Yet, the design characteristics, the policies and practices as well as the performance and impact of the UNGC have been controversial (Berliner and Prakash, 2015; Rasche, 2009; Rasche and Gilbert, 2012; Schembera, 2018; Sethi and Schepers, 2014).

The work of the appointed UN Special Representative on Business and Human Rights led to the development of the UNGPs, endorsed by the UN Human Rights Council in 2011. Although not legally binding, the UNGPs create a form of multilevel and polycentric governance system by establishing a set of global standards that cover all business enterprises and all human rights in all UN member states (Ruggie, 2013). The UNGPs include three interrelated pillars that lay out the roles, responsibilities and rights of the relevant actors in the business and human rights field: the states, companies, and victims of human rights abuses (OHCHR, 2012; OHCHR, 2014; OHCHR, 2011). The first pillar, 'state duty to protect human rights', confirms the role of the state as primary duty-bearer to protect human rights and its responsibility to prevent, investigate, punish and redress human rights abuses by companies. The second pillar, 'corporate responsibility to respect', includes the expectation that companies explicitly express their commitment to human rights by declaring their policy commitment to respect human rights, as well as by conducting 
human rights risk analysis and due diligence with respect to their business activities. The third pillar, 'access to remedy', requires the state and companies to establish governance structures that allow victims of human rights abuses to access effective remedy (Backer, 2011; Human Rights Council, 2008b; Ruggie, 2013).

The UNGPs for the first time define the role of business in general in the international human rights regime. Guiding principle 13 stipulates that the responsibility to respect human rights requires that businesses 'avoid causing or contributing to adverse human rights impacts through their own activities, and address such impacts when they occur; seek to prevent or mitigate adverse human rights impacts that are directly linked to their operations, products or services by their business relationships, even if they have not contributed to those impacts' (OHCHR, 2011).

Although controversially discussed (Backer, 2011; Deva, 2015; Ruggie, 2014; Wettstein, 2015), the UNGPs have proven very influential in affecting international human rights instruments. They were not only endorsed by the UN Human Rights Council, but also by regional bodies such as the European Union (EU), the Association of Southeast Asian Nations (ASEAN), and the Organisation of African States (OAS). They were used as a reference point in the OECD guidelines for multinational Enterprises (2011), the EU Directive 2014/95/EU on disclosure of non-financial and diversity information (2014), and the International Labour Organization (ILO)'s 'Tripartite Declaration of Principles concerning Multinational Enterprises and Social Policy (2017). The UNGPs are also incorporated into different international regulatory frameworks, such as the ISO 26000, the UN Global Compact, the Global Reporting Initiative, and the grievance mechanisms of development finance institutions. In addition, the UNGPs influenced hard law initiatives in several counties, such as the Modern Slavery Acts in the UK (2015) and Australia (2018), and the Corporate Duty of Vigilance Law in France (2017).

With respect to the debate on business and human rights at the UN level, the period of principled pragmatism (Ruggie, 2013) connected to the UNGPs has, since 2014, been followed by discussion of a business and human rights treaty (Deva and Bilchitz, 2017; McConnell, 2016), with a zero draft treaty on 'Legally binding instrument to regulate, in international human rights law, the activities of transnational corporations and other business enterprises' published by the UN intergovernmental working group on transnational corporations and other business enterprises with respect to human rights in 2018 (Intergouvernmental Working Group, 2018).

In addition to human rights initiatives at the UN level (Samarsinghe, 2018; Seppala, 2009), Barnaz (2017) introduces additional business- and human rights-related sources of national, transnational and international regulation, such as international economic law. 


\subsection{Corporate responsibility and involvement in human rights abuses}

The traditional notion in international law that sovereign states alone are responsible for the realization of human rights has been superseded by the view that companies should be held accountable for the human rights impact of their business activities (Muchlinski, 2001). Yet, only recently has CSR-oriented research turned towards the analysis of irresponsible corporate behaviour and corporate involvement in human rights abuses (Fiaschi, Giuliani, and Nieri, 2017; Giuliani, Macchi, and Fiaschi, 2014; Murphy and Schlegelmilch, 2013; Nieri, 2018).

Drawing on 350 entries of alleged corporate human rights violations archived at the Business and Human Rights Resource Centre, Wright (2008) shows that potentially the full range of human rights may be affected by irresponsible corporate activities (Table 1).

\section{Table 1: Corporate social irresponsibility: impacted human rights}

- Freedom of association

- Right to equal pay for equal work

- Right to equality at work

- Right to organize and participate in collective bargaining

- Right to non-discrimination

- Right to just and favourable remuneration

- Abolition of slavery and forced labour

- Right to a safe work environment

- Abolition of child labour

- Right to rest and leisure

- Right to work

- Right to family life

- Right to social security

- Freedom of movement

- Right to hold opinions, freedom of information and expression

Source: Adapted from Wright (2008)
- Right to life, liberty and security of the person

- Right of peaceful assembly

- Right to an adequate standard of living

- Freedom from torture or cruel, inhuman or degrading treatment

- Right to marry and form a family

- Right to physical and mental health; access to medical services

- Equal recognition and protection under the law

- Freedom of thought, conscience and religion

- Right to education

- Right to a fair trial

- Right to privacy

- Right to self-determination

- Right to political life

- Right to participate in cultural life, the benefits of scientific progress, and protection of authorial interests

A research report submitted to the UN (Commission on Human Rights, 2006) emphasises the significant variation in human rights abuses across sectors, and a link between human rights 


\section{MNES AND HUMAN RIGHTS: FROM RESPONSIBILITIES TO RIGHTS TO GOVERNANCE}

abuses and characteristics such as low national income, current or recent conflict and weak or corrupt governance.

According to Wettstein (2010), 'a large part of human rights violations with business involvement is not committed by the corporation itself, but by a third party which relies on benefits from the direct or indirect support of the company', such as a subsidiary or supplier. Clapham and Jerbi (2001) ask whether companies with 'operations in a country where human rights violations are widespread or where company revenues help support an oppressive regime' can be expected to 'influence government policies concerning human rights and the rule of law' or play a role 'in conflict prevention and resolution or in development efforts'.

The debate about direct and indirect corporate involvement in human rights abuses is multi-facetted and initially focused on companies being involved in serious violations of international law by the state' or acts that 'significantly contribute to the ability of the government to carry out systematic abuses of human rights' (Clapham and Jerbi, 2001). The discussion has recently broadened to include abuses by non-state actors (Human Rights Council, 2008a). The following section will introduce different approaches to analysing and categorizing corporate involvement in human rights approaches (Table 2).

Clapham and Jerbi (2001) and Wettstein (2010) distinguish different categories of corporate complicity from one another. Direct corporate complicity occurs if a company knowingly assists a state or non-state actor in human rights abuses, for example a company assisting the forced relocation of a community. Per Wettstein (2010), intent to do harm is not a necessary condition for complicity, whereas the intent to participate is. In a situation of beneficial corporate complicity, a company knowingly benefits from human rights abuses. For example, a joint venture partner or supplier providing labour services involving forced or child labour, or security services where staff are involved in human rights abuses such as suppressing peaceful protests. Silent complicity occurs when companies fail to 'raise systematic or continuous human rights abuses with the appropriate authorities' (Clapham and Jerbi, 2001). Wettstein (2010) adds an ethical dimension and distinguishes between direct and indirect complicity, the latter including beneficial and silent complicity. Indirect beneficial complicity would involve support for the ability of the perpetrator to carry out human rights abuses, e.g. by supporting the maintenance of a regime's financial and commercial infrastructure with tax payments and revenues, allowing a government to finance security forces involved in human rights abuses.

The concept of 'sphere of influence', emerging in the debate around the UNGC (Gasser, 2007), includes 'the individuals to whom [the business organization] has a certain political, contractual, economic or geographic proximity. Every business entity, whatever its size, will have 
a sphere of influence; the larger it is, the larger the sphere of influence is likely to be' (Commission on Human Rights, 2005). It maps the stakeholders in a company's value chain in the form of concentric circles, with the workforce at the core, and the supply chain, the marketplace, the community and governments in the respective outer circles, assuming that the influence of a company with respect to human rights issues is inversely related to the distance of the stakeholder from the core (Human Rights Council, 2008a).

While the 'sphere of influence' approach has been used to determine the scope and targets of company's social responsibilities, criticisms have been raised with respect to the definition and operationalisation of influence. Additionally, there is a significant gap between actors/stakeholders affected by human rights abuses and actors/stakeholders committing human rights abuses. Further criticisms relate to the leverage and control a company would have over actors involved in human rights abuses, as well as a lack of demarcation and clarity with respect to the allocation of obligations and duties between states and businesses (Gasser, 2007; Human Rights Council, 2008a; MacDonald, 2011).

A different approach was chosen by the UNGPs (OHCHR, 2011), which distinguish three types of corporate involvement in human rights abuse. First, a corporation may cause a human rights impact through its own activities, for example through direct racial discrimination against customers, exposing workers to hazardous working conditions without precautions, or polluting a communities' drinking water. Second, the company may contribute to the human rights impact through its own activities, either directly or through some external agent (government, business or other), for example by providing internet user data to a government that uses the data to trace and prosecute political dissidents, or performing construction and maintenance on a detention camp where inmates are subject to inhumane treatment. Third, it may be involved because the adverse human rights impact is caused by an agent it has a business relationship with and is linked to its own operations, products or services. Illustrations are financial loans to an enterprise for business activities that result in the eviction of communities in breach of agreed standards, or subcontracting to a supplier using illegal child labour.

While previous approaches usually take a micro-level perspective on the relationship between a human rights duty-bearer and human rights-holder, Macdonald's (2011) 'spheres of responsibility' approach also considers the impact of social institutions and the dynamics of institutionally-mediated action on the link between individual agency and human rights outcomes; for example, organisational configurations (e.g. supply chains or MNEs as networks of headquarters and subsidiaries) and social coordination mechanisms (e.g. markets). Through institutional mediation, e.g. in global value chains, companies can be involved in human rights 
abuses at a distance. In addition, it may constrain the extent to which a company can control human rights outcomes.

\section{Table 2: Approaches to corporate involvement in human rights abuses}

\begin{tabular}{l|l}
$\begin{array}{l}\text { Approaches and } \\
\text { categories }\end{array}$ & Brief description \\
\hline
\end{tabular}

Complicity approach (Clapham and Jerbi, 2001; Wettstein, 2010) $\Rightarrow$ focus on complicity

\begin{tabular}{c|l}
\hline A. Direct complicity & $\begin{array}{l}\text { Company 'knowingly assists a state or non-state actors in human } \\
\text { rights abuses' (Clapham and Jerbi, 2001). }\end{array}$ \\
\hline B. Indirect complicity & $\begin{array}{l}\text { Company does not directly contribute to abuse, but in a general way } \\
\text { 'supports the ability of the perpetrator to carry out systematic human } \\
\text { rights violations' (Wettstein, 2010). }\end{array}$ \\
\hline $\begin{array}{l}\text { B1. Silent } \\
\text { complicity }\end{array}$ & $\begin{array}{l}\text { Company fails to raise human rights abuses with the appropriate } \\
\text { authorities (Clapham and Jerbi, 2001). }\end{array}$ \\
\hline $\begin{array}{l}\text { B2. Beneficial } \\
\text { complicity }\end{array}$ & $\begin{array}{l}\text { A company knowingly 'benefits from human rights abuses committed } \\
\text { by somebody else' (Clapham and Jerbi, 2001). }\end{array}$ \\
\hline \hline
\end{tabular}

Cause-contribute-link approach (OHCHR, 2011; Ruggie, 2013) $\Rightarrow$ focus on impact

\begin{tabular}{l|l}
\hline A. Cause & Company causes a human rights impact through its own activities. \\
\hline B. Contribute & $\begin{array}{l}\text { Company contributes to a human rights impact through its own } \\
\text { activities, either directly or through an external agent. }\end{array}$ \\
\hline C. Linked & $\begin{array}{l}\text { Adverse impact is caused by an agent a company has a business } \\
\text { relationship with and is linked to its own operations, products or } \\
\text { services. }\end{array}$ \\
\hline \hline
\end{tabular}

Spheres of responsibility approach (MacDonald, 2011) $\Rightarrow$ focus on corporate duties

\begin{tabular}{c|l}
\hline $\begin{array}{l}\text { A. Distributed } \\
\text { negative duties... }\end{array}$ & $\begin{array}{l}\text {...involve distributed liabilities for abuses that can be allocated } \\
\text { between companies in an organisational configuration. }\end{array}$ \\
\hline $\begin{array}{l}\text { B. Derivative } \\
\text { positive duties }\end{array}$ & \\
\hline B1. Due diligence & Company should engage in human rights due diligence. \\
\hline B2. Coordination & $\begin{array}{l}\text { Company should coordinate inter-organisational decision-making } \\
\text { processes that have a link to human rights outcomes. }\end{array}$ \\
\hline $\begin{array}{l}\text { B3. Support } \\
\text { institutional change }\end{array}$ & $\begin{array}{l}\text { Company should support institutional change in order to remove } \\
\text { constraints on human rights realisation. }\end{array}$
\end{tabular}

This approach emphasises two categories of duties: distributed negative duties and derivative positive duties. Distributed negative duties involve distributed liabilities for human rights abuses 
MNES AND HUMAN RIGHTS: FROM RESPONSIBILITIES TO RIGHTS TO GOVERNANCE

that can be allocated between firms in a particular organisational configuration, e.g. members of a value chain. Derivative positive duties include three elements. First, companies should engage in human rights due diligence, which will involves human rights risk assessments in order to understand the nature of their impact on human rights-bearers. Second, companies should coordinate inter-organisational decision-making processes that have a link to human rights outcomes, e.g., in the form of multi-stakeholder initiatives. And, last but not least, companies have a positive duty to support institutional change in order to address the challenges of regulatory, market or wider social constraints on the realisation of human rights.

\subsection{Reflections on the current state of affairs}

The business and human rights debate has been driven by discussions around public policy initiatives at the UN level, many of which seek to establish standards to prevent and remedy human rights abuses linked to business activities. The following section will distil issues that arise from the current initiatives and debates.

First, the main soft- and hard-law initiatives presented above include a relatively clear definition of human rights, especially with respect to the rights-holder. However, there is less clarity on the role of business with respect to corporate responsibility and accountability, as indicated by the presentation of the different approaches to identify and categorise corporate involvement in human rights abuses (Table 2).

Second, initiatives at the UN level focus mainly on multinational enterprises or transnational business activities. The 2003 draft norms focus on 'transnational corporations' and any 'other business enterprise' that 'has any relation to a transnational corporation' (Commission on Human Rights, 2003). Only the 2011 UNGPs clearly and consistently focus on 'business enterprises' in almost universal terms. The 2018 zero draft treaty refers to 'business activities of a transnational character' (Intergouvernmental Working Group, 2018).

Third, previous discussions illustrate the dominance of both the legal perspective and the (business) ethics perspective in the field of business and human rights, reflected in the debates on responsibility and rights (Deva, 2012; Deva and Bilchitz, 2017; Wettstein, 2012; Wettstein, 2015). With respect to the role of companies in business and human rights, over time the debates connected to the legal perspective as well as those from the ethics/CSR-perspective have gradually moved from focusing on responsibility to focusing on rights, involving a shift from initially emphasizing the moral and ethical responsibilities of companies to later highlighting the legal responsibilities and obligation of business, for example in terms of access to justice and remedy for the human rights-holder negatively affected by corporate business activities. 
This has practical management implications: the change in focus from responsibilities to rights has led to a shift in management activities from discussing policies related to ethics and corporate social responsibility, as illustrated by the search for good practices and communicating the respective position and activities as part of non-financial reporting, towards systematically engaging in human rights risk analysis and due diligence, as well as establishing human rights compliance policies and human rights-related grievance mechanisms (Muchlinski, 2012).

Despite the growing academic literature on (international) business and human rights (Giuliani, 2018; Wettstein et al., 2019), management and social science research has not yet caught up pace with the legal and practical developments in the field, for example with respect to appropriate and effective governance and management of business and human rights issues (Zagelmeyer, Bianchi, and Shemberg, 2018). The following section will develop a framework with which to analyse business and human rights governance to better understand and analyse assumptions, interests, processes and conflicts in the business and human rights field.

\section{3 ... human rights governance as social value creation - A framework for analysing the business and human rights field}

This part of the paper introduces a framework for analysing human rights governance with respect to the business and human rights field in the context of the discussion on social value creation (Bergman, Teschemacher, Arora, Sengupta, Leisinger, and Bergman, 2019; Holmström Lind, Kang, Ljung, and Forsgren, 2019; Lashitew and van Tulder, 2019; Sinkovics, Sinkovics, Hoque, and Czaban, 2015; Sinkovics, Sinkovics, and Yamin, 2014), building on previous work developed in the field of industrial relations (Budd, 2004; Budd, 2013). The initial approach, which focuses on the employment relationship, i.e. the relationship between employer and employee, will be adapted to also cover the business and human rights subfields of labour, consumption, communities and the environment.

This section is divided into four subsections. The first subsection provides an introduction to the background to as well as the elements of the analytical framework. The second introduces the idea of the business and human rights field, which can itself be differentiated into subfields (labour, consumption, community relations and the environment), each organised around a dyadic relationship between duty-holders and rights-holders. The third subsection discusses the interests and objectives of the agents (or actors) involved in a human rights subfield at the individual (micro) level, as well as at the societal (macro) level. The fourth subsection elaborates on concepts and issues related to international business and human rights governance mechanisms, structures and systems. 
MNES AND HUMAN RIGHTS: FROM RESPONSIBILITIES TO RIGHTS TO GOVERNANCE

\subsection{Background and overview}

The analytical framework for analysing human rights governance builds on existing work in the field of industrial relations. The efficiency, equity and voice approach (Budd, 2004; Budd, 2013) provides a framework for analysing the employment relationship and labour relations processes, the role of agents, their interests, relationships and objectives with respect to the employment relationship. The framework itself belongs to the pluralist school of thought in industrial relations (Heery, 2016), and follows the tradition of institutionalist and systems theory-related approaches to industrial relations(Commons, 1934; Dunlop, 1958).

At the core of the framework are the three objectives of the employment relationship:

- efficiency: the profit-maximising use of scarce resources is related to economic efficiency in order to produce social value and wealth and represents a standard of economic performance;

- equity: the fair and just distribution of the outcomes of the economic value-creation process in society, including output and procedural justice, represents the standard of justice;

- voice: the meaningful participation of human beings and their representatives in decisionmaking procedures represents the standard of democratic involvement.

Different industrial relations actors, such as the government, employers, employees and their respective representatives, have individual and/or collective interests that are linked to the objectives of and outcomes from the employment relationship. The approach acknowledges the potential conflicts and trade-offs between the different types of human rights, e.g. property rights and labour rights. Property rights have traditionally been viewed as a foundation of individual freedom and liberty, and were included in the UDHR. With respect to the employment relationship, property rights serve economic efficiency as much as liberty purposes (Budd, 2004).

As interests and objectives may conflict or be shared across and between different actors and actor coalitions, the coordination of the respective activities in the employment relationship requires governance mechanisms and structures that resolve conflicts of interest and balance the respective objectives. For example, employers and/or supporters of market-based transactions may 'privilege property rights over workers' rights because basic economic theory shows that competitive markets and well-defined property rights are optimal for achieving efficiency' (Budd, 2013). Alternatively, proponents of democratic employee participation in decision-making may privilege individual political rights over property rights. The industrial relations system needs to balance the different objectives with respect to the employment relationship by devising institutionalised governance mechanisms and structures, such as collective bargaining, employee participation or labour law. 
Despite the connection to human rights as the contested terrain on which the efficiency, equity and voice approach is built, the approach is explicitly focused on analysis of the employment relationship. In what follows, this paper will extend the approach to cover additional human rights, including labour, consumer, community and environmental rights. In addition, the paper seeks to develop an approach that can be applied to social units other than the nation state.

Drawing on and using elements of the efficiency, equity and voice framework in order to develop a framework for international human rights governance serves several purposes. First, the framework allows for the identification and description of relevant actors and agents in the business and human rights field. Second, the framework helps identify and analyse relevant relationships between the different agents and actors. Third, the framework includes the potentially shared and conflicting interests of the actors, as well as different objectives related to the relationships between the actors. This allows scholars and practitioners to identify, explain and analyse areas of shared and conflicting interest, as well as the link between agents' interests and performance outcomes of the governance system. Finally, the approach enables us to compare and contrast the characteristics and performance implications of alternative governance structures regulating the relationships at different levels, considering different (country-based) systems.

At the core of the analytical framework is the idea that there is a business and human rights field, which includes the following characteristics and elements:

- agents (or actors): both individual agents (e.g. workers) and collective agents (e.g. trade unions);

- agent- (or actor-) specific interests: different agents may share the same interests or have conflicting individual and collective interests;

- relationships between the agents: agents are related to each other, for example through contractual arrangements;

- objectives of different relationships;

- governance mechanisms: the relationships between actors may be governed through different governance mechanisms.

\subsection{The business and human rights field, actors and relationships}

While the framework aspires to generally apply to all aspects of business and human rights, the following sections distinguish between four different human rights subfields (Table 3), each consisting of a particular set of actors engaging in relationships that have potential human rights 
implications: labour, consumption, community and environment (ORCHR, 2017; Zagelmeyer, Bianchi, and Shemberg, 2018).

First, the labour subfield is organised around the relationship between entities using labour as input factor in the production of goods or services (e.g., the employer in industrial relations terminology) and the individual person providing labour services (e.g., the employee). The labour subfield may also include work arrangement beyond the employment relationship, such as slave labour and forced labour. Second, the consumer subfield includes the relationship between the provider of goods and services and the consumer. Third, the community subfield includes relationships between companies and individuals in communities affected by relevant business operations. Finally, the environment subfield involves the relationship between the companies and the rights-holders who hold rights in the physical and biological environment relevant to and affected by the respective business activities.

The distinction between these subfields can be justified by the existence of different sets of factors that engage in subfield-specific relationships and subfield-specific interests, and/or objectives and outcomes. An alternative but related justification is that each human rights subfield is organised around a subset-specific configuration of human rights, duty-bearers, and rightsholders. As the approach is intended to be generally applicable to a wide range of countries with specific actor constellations and institutions, it does not seek to be excessively specific.

Each of the four human rights subfields has a specific configuration of actors and relationships. Two primary actors are directly connected in a dyadic relationship, namely the human rights duty-bearer on one side, and the actor whose human rights could potentially be harmed by business activities, the rights-holder, on the other. The human rights of individuals or groups may be harmed in relation to their roles as worker, consumer, community member, and individual living in a particular environment.

At this point it is important to note that the primary actors can (but do not need to) have a contractual relationship with each other. Human rights-related relationships may exist between the company and a human rights-holder in a situation where no direct contractual relationship exists. For example, let us consider a situation in which a child is negatively affected in his or her human rights through the consumption of a product, which was contaminated in the production process and subsequently purchased by the child's father. In this case, the seller and duty-bearer would be the producing company, the buyer would be the father, and the human rights-bearer would be the child. Another illustration of unintended external or spill-over effects might be the right to clean water of community members if a manufacturing facility is involved in water 
pollution, but does not have any direct contractual relationship with the community or community members.

In addition, each of the subfields may include secondary actors. These are not directly involved as parties to the dyadic relationship, but they may be authorised to represent primary actors in matters relating to the relationship between the primary actors. For example, trade unions may represent individual employees in wage negotiations; governments may provide a legal framework governing the dyadic relationship; or the state-based judiciary may play a role in the establishment or operation of grievance procedures.

Table 3: Human rights subfields, actors and relationships

\begin{tabular}{l||l|l||l}
\multicolumn{1}{c||}{$\begin{array}{c}\text { Human rights } \\
\text { subfields }\end{array}$} & \multicolumn{2}{c||}{$\begin{array}{c}\text { Primary actors and } \\
\text { dyadic relationships }\end{array}$} & \multicolumn{1}{c}{$\begin{array}{c}\text { Secondary actors } \\
\text { (e.g.) }\end{array}$} \\
\hline \hline Labour & Duty bearers & \multicolumn{1}{c}{ Rights holders } & \\
\hline Consumption & Business & Worker & $\begin{array}{l}\text { Trade unions, employers' } \\
\text { associations, government/s }\end{array}$ \\
\hline Community & Business & $\begin{array}{l}\text { Member/s of a community } \\
\text { or the whole community }\end{array}$ & NGOs/CSOs, government/s \\
& & NGOs/CSOs, trade \\
associations, government/s
\end{tabular}

Key: $\mathrm{NGO}=$ non-governmental organization; $\mathrm{CSO}=$ civil society organization.

\subsection{Actor interests and the balance of objectives in the business and human rights field}

In each of the subfields, the actors engage in the field with specific objectives, i.e. they expect particular outcomes in terms of efficiency, equity and voice. Each individual and collective actor has their own specific set of interests, which influences their choice of strategy and provides motivation to engage in goal-directed behaviour and activities. Actors may share interests, but there could also be conflicts of interest between different actors.

In the labour subfield, one can usually assume a shared interest between employer and employee given that they are engaged in an employment relationship, but there may be areas of inherent conflict of interest with respect to substantive issues. For example, wage increases directly translate into higher costs, which may ultimately reduce profitability (unless wage increases are fully compensated by productivity increases), which is not in the interests of profit- 
maximising employers. However, for income-maximising employees, wage increases may generate additional income and purchasing power. A similar line of reasoning applies to the consumption subfield, with buyers and sellers having an interest in engaging in a commercial relationship, but where the relationship faces an inherent conflict of interest with respect to the price and quality of products or services.

The community subfield and the environment subfield often do not involve a direct contractual relationship between the human rights duty-bearer (i.e. the business organisations) and the human rights-holders (i.e. individuals or groups living in a particular community or environment). Yet, there may be conflicts of interest between different actors. With respect to the community subfield, local communities and/or government(s) may have an interest in attracting business investment to support social and economic development. For example, production facilities may create jobs and tax revenue for the local community. On the other hand, members of the local community may be negatively affected in the exercise of the human rights, for example through sexual abuse committed by security forces related to the factory or water pollution as a consequence of inadequate environmental provisions and standards at local production facilities. In both cases, the human rights-holders may not have a direct contractual relationship with the respective business organisation, which would be established, for example, with a local government agency.

Assuming overlapping, competing and conflicting interests between the different actors, each dyadic relationship between duty-bearers and rights-holders can be interpreted as a bargaining problem that raises questions about the relative distribution of power between the actors in the dyadic relationship, and the rules governing their interactions, i.e. governance. For example, with respect to the labour subfield, the pluralist view of the employment relationship argues that employers focus on profit maximisation and considers that work is not just a commodity traded in labour markets, but that the production factor of labour is provided by human beings with aspirations, feelings, emotions, needs, and rights. As a consequence of this, Budd (2004) abandons the idea that allocative efficiency is the only objective, but adds equity (and fairness), which includes fair standards for both material outcomes and personal treatment as objectives to the relationship between the different actors. In addition, he emphasises the importance of voice (or democratic participation in decision-making), defined as 'the ability to have meaningful input into decisions' that impact human rights-holders (Budd, 2004). The main argument in favour of distinguishing between equity and voice is that equity is instrumental and can be provided unilaterally by employers or government regulations, while voice can only be achieved through the active participation of employees. 
MNES AND HUMAN RIGHTS: FROM RESPONSIBILITIES TO RIGHTS TO GOVERNANCE

The concepts of efficiency, equity and voice represent explicit normative objectives with respect to the economic and social coordination activities between different actors. At the level of the individual actor (e.g. the duty-bearer and the right-holder), there may be different preferences and values attached to the different goals. Profit-maximising companies may prefer efficiency over equity and voice, while workers may prefer equity and voice over efficiency. However, it may also be that different actors have a shared interest in one particular goal.

While the initial efficiency, equity and voice approach focuses on the employment relationship (Budd, 2004), its core ideas can be used to analyse the three other human rights subfields of labour, consumption, the community and the environment. Depending on the characteristics of the different dyadic relationships, the actors may have overlapping and conflicting interests and may pursue different objectives, and thus society needs to find a way to achieve a workable balance of objectives. This balance needs to equally apply at the (micro) level of the dyadic relationships as well as at the societal (macro) level. With respect to the latter, efficiency, equity and voice approach can be reinterpreted to address the issues of the broader societal objectives wealth, justice and democracy. Assuming that human rights are absolute and universal, the potential tensions between the realisation of different human rights (e.g. property rights and labour rights) show the need for balancing the three objectives. This can be done through the establishment of a human rights governance system that includes a specific configuration of governance structures for the different human rights subfields at the micro- and macro-levels.

\subsection{Business and human rights governance: mechanisms, systems, and strategies}

A business and human rights governance system involves a specific configuration of governance structures, which provide the formal and informal institutional rules for the relationships between the different actors in the business and human rights field or a specific subfield.

Williamson (1996) defines governance as 'an institutional framework in which the integrity of a transaction or related set of transactions is decided', aiming 'to effect good order through the mechanisms of governance.' Governance structures involve decision-making procedures for regulating and governing relationships between actors (Dow, 1987) and, following Frey (1981), governance mechanisms can include the market (through the price mechanism), democracy (through political decision-making processes), bureaucracy or hierarchy (through centralized decision-making), or the interaction of collective actors or interest groups (in collective bargaining). According to whether or not state or state agencies are involved in governance, we can distinguish between public and private governance. 
Within a human rights governance system, in general or with respect to the different human rights subfields, a relationship between two or more actors may be covered and regulated by a multiplicity of governance mechanisms and structures at different levels, e.g. individual level, company level, national level, or international level. A human rights governance system thus consists of a specific arrangement or configuration of governance structures within a defined entity, such as an industry, a firm, a country or a value chain, in which each relationship can be regulated through different configurations of governance systems. 'Good' governance of the respective relationship requires that the different objectives are balanced.

While the detailed description, exploration and analysis of governance mechanisms, structures and systems for the different types of relationships between actors in the business and human rights field and its subfields is beyond the scope of this paper, the following illustration may provide a first glance at issues potentially involved in such analysis.

In the business and human rights field as well as in each of the subfields, the actors get involved in relationships, be they on a contractual basis (for example, employer and worker, or seller and buyer), or a non-contractual basis (for example, a mining company operating in a particular local community). In each of the settings, the business organisation has the role of human rights duty-bearer, and individuals or groups represent human rights-holders. Each of the actors involved has specific interests, and potentially overlapping and/or conflicting views with respect to the objectives of the relationships in the respective field or subfield.

Depending on a number of contingencies, each of the actors has a specific set of strategies available, which can be chosen to achieve the desired perspectives from the relationship. For example, assuming profit-maximising behaviour, corporations have different strategic choice options that are conducive to their own (efficiency) objective. The range of strategic choice options may include market and non-market strategies. The latter may include political influencing and lobbying activities that seek to influence the configuration and operation of the respective governance system. In addition, business organisations could pursue the establishment of private governance structures between non-state actors, which either unilaterally or collectively regulate the respective relationships. While unilateral regulation may be based on philanthropic or paternalistic motivations, collective regulation may include involvement in multi-stakeholder initiatives or joint regulation, for example through collective bargaining with trade unions.

It is important to note that the business and human rights governance approach is based on a pragmatic and pluralist approach to governance, public policy and law, which assumes that there are different legitimate actors with overlapping but also potentially conflicting interests 
operating in existing fields, and that the conflicts between different actors can be resolved via a mix of private and public institutional procedures, which make up for or 'correct' the governance system. In terms of schools of thought on human rights, this approach is closely related to the pluralist school of human rights. However, there are alternative assumptions and views on the nature of, and the relationships between, the actors in the business and human rights field (or the respective subfield), for example the natural school or the discourse schools of thought on human rights (Dembour, 2010), or the critical or radical perspective on industrial relations (Budd, 2004; Heery, 2016). Analyses based on different assumptions and views may arrive at different conclusions about the adequacy and effectiveness of governance structures.

\section{Conclusions and outlook}

A review of relevant human rights initiatives and approaches to corporate complicity revealed (i) the challenges of identifying and analysing the role of business in human rights abuses; and (ii) a shift in the focus of the business and human rights debate from responsibility towards rights. The 2011 UNGPs, while reaffirming the role of the state in human rights protection, requires companies to respect human rights, and demands that states and business provide effective remedies. They thus establish the nucleus for a polycentric business and human rights governance system, which includes elements of both private and public governance. Yet, the tools to describe, analyse and evaluate business and human rights governance are still largely missing.

This paper suggests a framework for analysing international business and human rights governance, drawing on elements from Budd (2004)'s efficiency, equity and voice approach (2004). The framework is organised around relationships between human rights duty-bearers and rights holders in human rights subfields. It emphasises the role of actors and their interests, the relationships between actors, the objectives of these relationships (efficiency, equity and voice), and the role of governance mechanisms and structures, which define the governance system.

The proposed analytical framework can contribute in different ways to IB research. First, the framework can be used to identify and describe relevant actors, their assumptions, interests and objectives, as well as their bi- or multilateral relationships in the respective international business and human rights field. Actors may include, for example, MNEs, overseas subsidiaries and suppliers as human rights duty-bearers on the IB and management side. On the side of human rights-holders, actors may include workers, consumers and community members, as well as civil society organisations and government agencies. This analysis could shed further light on the strategies used by companies to deal with potential human rights issues. 
Furthermore, the framework can support the analysis of the human rights implications of IB-related activities, such as international trade, foreign direct investment, different modes of foreign market entry or operation, or specific organisational configurations of pursuing IB activities such as global value chains (Gereffi, 2014; Gereffi, Humphrey, and Sturgeon, 2005), international supply chains (Nolan, 2017), global production networks (Barrientos, Mayer, Pickles, and Posthuma, 2011) or the global factory (Buckley and Strange, 2015). It can be adjusted to consider multilevel factors, for example actors and relationships at the organizational, local, national, transnational and/or international level.

In addition, the framework can inform the analysis and discussion of the assumptions, interests and potential conflicts between the different actors or actor constellations in the respective international human rights subfield with respect to the normative goals of efficiency, equity and voice or the broader societal goals of wealth, justice and democracy. This also includes the comparative normative analysis of alternative institutional arrangements at different levels, for example to compare and contrast the relative advantages and disadvantages of different configurations of business and human rights-related grievance mechanisms. The framework can also be used for positive empirical analysis, for example by deriving implications and predictions that can be empirically tested, such the link between actor constellations and the three objectives, or the performance outcomes of different configurations of governance systems. For example, one hypothesis could be that unbalanced outcomes - related to efficiency, equity and voice - are unstable and short-lived, while a balance between competing interests leads to a higher degree of acceptance and stability and trust in the respective relationship between actors (micro-level), but also at societal level (macro-level).

Finally, the framework is of practical relevance for international managers and public policy-makers. MNEs operating in different countries and different institutional settings may face quite complex business and human rights challenges. The framework presented in this paper may help management and public policy-makers to analyse the different business and human rights subfields, as well as the respective business and human rights governance systems, which may then inform the development and design of corporate non-market strategies and/or public policies in the field of business and human rights. 
MNES AND HUMAN RIGHTS: FROM RESPONSIBILITIES TO RIGHTS TO GOVERNANCE

\section{List of References}

Backer, L.C. (2011), "On the evolution of the United Nations "Protect-Respect-Remedy Project": The state, the corporation and human rights in a global governance context", Santa Clara Journal of International Law, Vol. 9 No. 2, pp. 37-80.

Banerjee, S.B. (2014), "A critical perspective on corporate social responsibility - Towards a global governance framework", Critical Perspectives on International Business, Vol. 10 No. 1/2, pp. 84-95.

Barrientos, S., Mayer, F., Pickles, J., and Posthuma, A. (2011), "Decent work in global production networks: Framing the policy debate", International Labour Review, Vol. 150 No. 3-4, pp. 297-317.

Bergman, Z., Teschemacher, Y., Arora, B., Sengupta, R., Leisinger, K.M., and Bergman, M.M. (2019), "Developing the business-society nexus through corporate responsibility expectations in India", Critical perspectives on international business, pp. Advance online publication.

Berliner, D. and Prakash, A. (2015), "'Bluewashing' the firm? Voluntary regulations, program design, and member compliance with the United Nations Global Compact", Policy Studies Journal, Vol. 43 No. 1, pp. 115-38.

Buckley, P.J., Doh, J.P., and Benischke, M.H. (2017), "Towards a renaissance in international business research? Big questions, grand challenges, and the future of IB scholarship", Journal of International Business Studies, Vol. 48 No. 9, pp. 1045-64.

Buckley, P.J. and Strange, R. (2015), "The governance of the global factory: location and control of world economic activity", The Academy of Management Perspectives, Vol. 29 No. 2, pp. 237-49.

Budd, J.W. (2004), Employment with a human face: Balancing efficiency, equity and voice, Cornell University Press, Ithaca, New York.

Budd, J.W. (2013), Labor relations: Striking a balance (4th ed.), McGraw-Hill/Irwin, New York.

Campagna, J. (2004), "United Nations norms on the responsibilities of transnational corporations and other business enterprises with regard to human tights: The international community asserts binding law on global rule makers", Marshall Law Review, Vol. 37, pp. 1205-52.

Clapham, A. and Jerbi, S. (2001), "Categories of coporate complicity in human rights abuses", Hastings International and Comparative Law Review, Vol. 24, pp. 339-49.

Commission on Human Rights (2003), "Economic, social and cultural rights - Draft norms on the responsibilities of transnational corporations and other business enterprises with regard to human rights," United Nations. Economic and Social Council. E/CN.4/Sub.2/2003/12. 30 May 2003.

Commission on Human Rights (2005), "Report of the Sub-Commission on the Promotion and Protection of Human Rights: Report of the United Nations High Commissioner on Human Rights on the responsibilities of transnational corporations and related business enterprises with regard to human rights," United Nations. Economic and Social Council. E/CN.4/2005/91. 15 Fenruary 2005.

Commission on Human Rights (2006), "Promotion and protection of human rights: Interim report of the Special Representative of the Secretary-General on the issue of human rights and transnational corporations and other business enterprises," United Nations. Economic and Social Council. E/CN.4/2006/97. 22 February 2006.

Commons, J.R. (1934), Institutional economics - Its place in political economy, Macmillan, New York.

de Jonge, A. (2011), "Transnational corporations and international law: Bringing TNCs out of the accountability vacuum", Critical Perspectives on International Business, Vol. 7 No. 1, pp. 66-89. 
Dembour, M.-B. (2010), "What are human rights? Four schools of thought", Human Rights Quarterly, Vol. 32 No. 1, pp. 1-20.

Deva, S. (2012), Regulating corporate human rights violations - Humanizing business, Routledge, London.

Deva, S. (2015), "Protect, Respect and Remedy': A critique of the SRSG's framework for business and human rights", in Buhmann, K., Roseberry, L., and Morsing, M. (Eds.), Corporate social and human rights tesponsibilities, Palgrave Macmillan, Houndmills, pp. 108-26.

Deva, S. and Bilchitz, D. (2017), Building a trreaty on business and human rights - Context and contours, Cambridge University Press, Cambridge.

Dow, G.K. (1987), "The function of authority in transaction cost economics", Journal of Economic Behavior \& Organization, Vol. 8 No. 1, pp. 13-38.

Dunlop, J.T. (1958), Industrial relations systems, Holt, New York.

Feeney, P. (2009), "Business andd human rights: The struggle for accountability in the UN and the future direction of the advocacy agenda", Sur - International Journal on Human Rights, Vol. 6, pp. 174-91.

Fiaschi, D., Giuliani, E., and Nieri, F. (2017), "Overcoming the liability of origin by doing noharm: Emerging country firms' social irresponsibility as they go global", Journal of World Business, Vol. 52 No. 4, pp. 546-63.

Frey, B.S. (1981), Theorie demokratischer Wirtschaftspolitik, Vahlen, Munich.

Gasser, U. (2007), "Responsibility for human rights violations, acts or omissions, within the sphere of influence of companies," The Berkman Center for Internet \& Society at Harvard Law School - Research Publication No. 2007-12.

Gereffi, G. (2014), "Global value chains in a post-Washington Consensus world", Review of International Political Economy, Vol. 21 No. 1, pp. 9-37.

Gereffi, G., Humphrey, J., and Sturgeon, T. (2005), "The governance of global value chains", Review of International Political Economy, Vol. 12 No. 1, pp. 78-104.

Giuliani, E. (2018), "Why multinational enterprises may be causing more inequality than we think", Multinational Business Review. Doi: 10.1108/MBR-10-2018-0068.

Giuliani, E. and Macchi, C. (2014), "Multinational corporations' economic and human rights impacts on developing countries: a review and research agenda", Cambridge Journal of Economics, Vol. 38 No. 2, pp. 479-517.

Giuliani, E., Macchi, C., and Fiaschi, D. (2014), "The social irresponsibility of international business: A novel conceptualization", in Van Tulder, R., Verbeke, A., and Strange, R. (Eds.), International Business and Sustainable Development Vol. 8, Emerald, pp. 141-71.

Giuliani, E., Santangelo, G.D., and Wettstein, F. (2016), "Human rights and international business research: A call for studying emerging market multinationals", Management and Organization Review, Vol. 12 No. 3, pp. 631-37.

Heery, E. (2016), Framing work: Unitary, pluralist, and critical perspectives in the twenty-first century, Oxford University Press, New York NY.

Holmström Lind, C., Kang, O., Ljung, A., and Forsgren, M. (2019), "MNC involvement in social innovations: the issue of knowledge, networks and power", Critical perspectives on international business, pp. Advance online publication.

Human Rights Council (2008a), "Promotion and protection of all human rights, civil, political, economic, social and cultural rights, including the right to development: Clarifying the concepts of "sphere of influence" and "complicity"," Report of the Special Representative of the Secretary-General on the Issue of Human Rights and Transnational Corporations and other Business Enterprises, John Ruggie. UN Human Rights Council, A/HRC/8/16. 15 May 2008. 
MNES AND HUMAN RIGHTS: FROM RESPONSIBILITIES TO RIGHTS TO GOVERNANCE

Human Rights Council (2008b), "Promotion and protection of all human rights, civil, political, economic, social and cultural rights, including the right to development: Protect, respect and remedy - A framework for business and human rights ", Report of the Special Representative of the Secretary-General on the Issue of Human Rights and Transnational Corporations and other Business Enterprises, John Ruggie. UN Human Rights Council, A/HRC/8/5. 7 April 2008.

Intergouvernmental Working Group (2018), "Legally binding Instrument to regulate, in International Human Rights Law, the Activities of Transnational Corporations and other Business Enterprises - Zero Draft 16.7.2018."

Lashitew, A.A. and van Tulder, R. (2019), "The limits and promises of embeddedness as a strategy for social value creation", Critical perspectives on international business, pp. Advance online publication.

MacDonald, K. (2011), "Re-thinking 'spheres of responsibility': Business responsibility for indirect harm", Journal of Business Ethics, Vol. 99 No. 4, pp. 549-63.

McConnell, L. (2016), "Assessing the feasibility of a business and human rights treaty", International and Comparative Law Quarterly, Vol. 66 No. 01, pp. 143-80.

Muchlinski, P. (2012), "Implementing the new UN corporate human rights framework: Implications for corporate law, governance, and regulation", Business Ethics Quarterly, Vol. 22 No. 1, pp. 145-77.

Muchlinski, P.T. (2001), "Human rights and multinationals: Is there a problem?", International Affairs, Vol. 77 No. 1, pp. 31-47.

Murphy, P.E. and Schlegelmilch, B.B. (2013), "Corporate social responsibility and corporate social irresponsibility: Introduction to a special topic section", Journal of Business Research, Vol. 66 No. 10, pp. 1807-13.

Nieri, F.G., E. (2018), "International business and corporate wrongdoing: A review and research agenda ", in Castellani, D., Narula, R., Nguyen, Q.T.K., Surdu, I., and Walker, J.T. (Eds.), Institutions, Strategy and Performance, Palgrave, Cham, pp. 35-54.

Nolan, J. (2017), "Business and human rights: The challenge of putting principles into practice and regulating global supply chains", Alternative Law Journal, Vol. 42 No. 1, pp. 42-46.

OHCHR (2011), "Guiding principles on business and human rights - Implementing the United Nations "Protect, Respect and Remedy" framework," Office of the UN High Commissioner for Human Rights, Geneva.

OHCHR (2012), "The corporate responsibility to respect human rights: An Interpretive guide," Office of the UN High Commissioner for Human Rights, Geneva.

OHCHR (2014), "Frequently asked questions about the Guiding Principles on Business and Human Rights," Office of the UN High Commissioner for Human Rights, Geneva.

ORCHR (2017), "Access to remedy for business-related human rights abuses - A scoping paper on State-based non-judicial mechanisms relevant for the respct by business enterprises for human rights: current issues, preactices and challenges," Office of the UN High Commissioner for Human Rights, Geneva.

Pisani, N., Kourula, A., Kolk, A., and Meijer, R. (2017), "How global is international CSR research? Insights and recommendations from a systematic review", Journal of World Business, Vol. 52 No. 5, pp. 591-614.

Rasche, A. (2009), "'A necessary supplement": What the United Nations Global Compact is and is not", Business \& Society, Vol. 48 No. 4, pp. 511-37.

Rasche, A. and Gilbert, D.U. (2012), "Institutionalizing global governance: the role of the United Nations Global Compact", Business Ethics: A European Review, Vol. 21 No. 1, pp. 10014.

Rasche, A., Waddock, S., and McIntosh, M. (2013), "The United Nations Global Compact: Retrospect and prospect", Business \& Society, Vol. 52, pp. 6-30. 
MNES AND HUMAN RIGHTS: FROM RESPONSIBILITIES TO RIGHTS TO GOVERNANCE

Ruggie, J.G. (2013), Just business: Multinational corporations and human rights, W.W. Norton, New York.

Ruggie, J.G. (2014), "Global governance and "New Governance Theory": Lessons from business and human rights", Global Governance, Vol. 20 No. 1, pp. 5-17.

Samarsinghe, N. (2018), "Human rights: Norms and machinery", in Weiss, T.G. and Daws, S. (Eds.), The Oxford Handbook on the United Nations, 2nd ed., Oxford University Press, Oxford, pp. 543-66.

Sauvant, K.P. (2015), "The negotiations of the United Nations Code of Conduct on Transnational Corporations - Experience and lessons learned", The Journal Of World Investment \& Trade, Vol. 16, pp. 11-87.

Schembera, S. (2018), "Implementing corporate social responsibility: Empirical insights on the impact of the UN Global Compact on its business participants", Business \& Society, Vol. 57 No. 5 , pp. $783-825$.

Seppala, N. (2009), "Business and the international human rights regime: A comparison of UN initiatives", Journal of Business Ethics, Vol. 87 No. 2, pp. 401-17.

Sethi, S.P. and Schepers, D.H. (2014), "United Nations Global Compact: The promiseperformance gap", Journal of Business Ethics, Vol. 122 No. 2, pp. 193-208.

Sinkovics, N., Hoque, S.F., and Sinkovics, R.R. (2016), "Rana Plaza collapse aftermath: are CSR compliance and auditing pressures effective?", Accounting, Auditing \& Accountability Journal, Vol. 29 No. 4, pp. 617-49.

Sinkovics, N., Sinkovics, R.R., Hoque, S.F., and Czaban, L. (2015), "A reconceptualisation of social value creation as social constraint alleviation", Critical perspectives on international business, Vol. 11 No. 3/4, pp. 340-63.

Sinkovics, N., Sinkovics, R.R., and Yamin, M. (2014), "The role of social value creation in business model formulation at the bottom of the pyramid - Implications for MNEs?", International Business Review, Vol. 23 No. 4, pp. 692-707.

United Nations Global Compact (2019), What is the UN Global Compact?, Available (Accessed, 1 March 2019) https://www.unglobalcompact.org/what-is-gc.

van Zanten, J.A. and van Tulder, R. (2018), "Multinational enterprises and the Sustainable Development Goals: An institutional approach to corporate engagement", Journal of International Business Policy, Vol. 1 No. 3, pp. 208-33.

Weissbrodt, D. (2005), "Business and human rights", University of Cincinnati Law Review, Vol. 74 , pp. 55-73.

Weissbrodt, D. (2008), "Keynote address: International standard-setting on the human rights responsibilities of businesses", Berkeley Journal of International Law, Vol. 26 No. 2, pp. 373-91.

Wettstein, F. (2010), "The duty to protect: Corporate complicity, political responsibility, and human rights advocacy", Journal of Business Ethics, Vol. 96 No. 1, pp. 33-47.

Wettstein, F. (2012), "CSR and the debate on business and human rights: Bridging the great divide", Business Ethics Quarterly, Vol. 22 No. 4, pp. 739-70.

Wettstein, F. (2015), "Normativity, ethics, and the UN Guiding Principles on Business and Human Rights: A critical assessment", Journal of Human Rights, Vol. 14 No. 2, pp. 16282.

Wettstein, F., Giuliani, E., Santangelo, G.D., and Stahl, G.K. (2019), "International business and human rights: A research agenda", Journal of World Business, Vol. 54 No. 1, pp. 54-65.

Williams, O.F. (2004), "The UN Global Compact: The challenge and the promise", Business Ethics Quarterly, Vol. 14 No. 4, pp. 755-74.

Williams, O.F. (2014), "The United Nations Global Compact: What did it promise?", Journal of Business Ethics, Vol. 122 No. 2, pp. 241-51.

Williamson, O.E. (1996), The mechanisms of governance, Oxford University Press, Oxford. 
Wright, M. (2008), "Corporations and human rights - Scope and patterns of the alleged corporaterelated human rights abuse," Corporate social responsibility initiative working paper No. 44. John F. Kennedy School of Government, Harvard University. Cambridge, Massachusetts.

Zagelmeyer, S., Bianchi, L., and Shemberg, A.R. (2018), "Non-state based non-judicial grievance mechanisms (NSBGM): An exploratory analysis - A report prepared for the Office of the UN High Commissioner for Human Rights." 